\title{
ISOKINETIC EVALUATION OF KNEE MUSCLES IN SOCCER PLAYERS: DISCRIMINANT ANALYSIS
}

\author{
AVALIAÇÃO ISOCINÉTICA DOS MÚSCULOS DO JOELHO EM JOGADORES DE FUTEBOL: \\ ANÁLISE DISCRIMINANTE
}

Original Article ARTIGO ORIGINAL Artículo Original

\author{
EVALUACIÓN ISOCINÉTICA DE LOS MÚSCULOS DE LA RODILLA EN JUGADORES DE FÚTBOL: \\ ANÁLISIS DISCRIMINANTE
}

\begin{abstract}
Bruno Fles Mazuquin (Physical Therapist)

Ligia Maxwell Pereira² (Physical Therapist)

Josilainne Marcelino Dias ${ }^{2}$ (Physical Therapist)

João Pedro Batista Junior ${ }^{3}$

(Physical Therapist) (Physical Therapist)

Matheus Elmer Finatti ${ }^{4}$

(Physical Therapist)

Lucas Carvalho Leme ${ }^{5}$

(Physical Education)

Rodrigo Luiz Carregaro ${ }^{6}$

(Physical Therapist)

Felipe Arruda Moura²

(Physical Education)

Jefferson Rosa Cardoso’

(Physical Therapist)
\end{abstract}

Mônica Angélica Cardoso Silva ${ }^{4}$

1. University of Central Lancashire (UCLAN), Preston, United Kingdom. 2. Universidade Estadual de Londrina (UEL), Londrina, PR, Brazil. 3. Instituto Federal do Paraná (IFPR), Londrina, PR, Brazil.

4. Clube Atlético Paranaense,

Curitiba, PR, Brazil.

5. Londrina Esporte Clube, Londrina, PR, Brazil.

6. Universidade de Brasília (UNB), Brasília, DF, Brazil.

7. Laboratório de Biomecânica e Epidemiologia Clínica - Grupo de Pesquisa (PAIFIT), UEL, Londrina, $P R$, Brazil.

Correspondence: Jefferson Rosa Cardoso, Hospital Universitário, Universidade Estadual de Londrina. Av. Robert Kock, 60. 86038-440, Londrina, PR, Brazil. jeffcar@uel.br

\begin{abstract}
Introduction: Muscle activity in soccer players can be measured by isokinetic dynamometer, which is a reliable tool for assessing human performance. Objectives: To perform isokinetic analyses and to determine which variables differentiate the under-17 (U17) soccer category from the professional (PRO). Methods: Thirty-four players were assessed ( $n=17$ for each category). The isokinetic variables used for the knee extension-flexion analysis were: peak torque ( $\mathrm{Nm}$ ), total work $(\mathrm{J})$, average power $(\mathrm{W})$, angle of peak torque (deg.), agonist/ antagonist ratio (\%), measured for three velocities $(60 \%, \mathrm{~s}, 120 \% \mathrm{~s}$ and $300 \% \mathrm{~s})$, with each series containing five repetitions. Three Wilks' Lambda discriminant analyses were performed, to identify which variables were more significant for the definition of each of the categories. Results: The discriminative variables at $60 \% \mathrm{~s}$ in the PRO category were: extension peak torque, flexion total work, extension average power and agonist/antagonist ratio; and for the U17s were: extension total work, flexion peak torque and flexion average power. At $120 \% \mathrm{~s}$ for the PRO category the discriminant variables were: flexion peak torque and extension average power; for the U17s they were: extension total work and flexion average power. Finally at $300 \%$, the variables found in the PRO and U17 categories respectively were: extension average power and extension total work. Conclusion: Isokinetic variables for flexion and extension knee muscles were able to significantly discriminate between PRO and U17 soccer players.
\end{abstract}

Keywords: knee, muscle strength dynamometer, soccer, discriminant analysis.

\section{RESUMO}

Introdução: A atividade muscular em jogadores de futebol pode ser medida por meio do dinamômetro isocinético, que é um instrumento confiável para avaliação do desempenho humano. Objetivos: Conduzir análises isocinéticas e discriminar quais variáveis diferenciam a categoria sub-17 (S17) da profissional (PRO). Métodos: Trinta e quatro jogadores de futebol ( $n=17$ para cada categoria) foram avaliados. As variáveis isocinéticas utilizadas para a análise de extensão-flexão do joelho foram: pico de torque (Nm), trabalho total (J), potência média (W), ângulo de pico de torque (graus), razão agonista/antagonista (\%), testadas em três velocidades $(60 \%, 120 \%$ s e $300 \%$ s), com cada série contendo cinco repetições. Três análises discriminantes foram feitas usando o método Wilk's Lambda para identificar quais variáveis fariam uma discriminação significativa entre as duas categorias. Resultados: As variáveis discriminantes a $60 \%$ s na categoria PRO foram: pico de torque extensores, trabalho total flexores, potência média de extensores e razão agonista/antagonista; e para os $S 17$ foram: trabalho total de extensores, pico de torque de flexores e potência média de flexores. A $120 \%$ s para a categoria PRO as variáveis discriminantes foram: pico de torque de flexores e potência média de extensores; para os 517 foram: trabalho total de extensores e potência média de flexores. A 300\%s, as variáveis encontradas para as categorias PRO e 517 foram, respectivamente: potência média de extensores e trabalho total de extensores. Conclusão: As variáveis isocinéticas para os músculos do joelho flexores e extensores foram capazes de fazer uma discriminação significativa entre jogadores de futebol PRO e S17.

Palavras-chave: joelho, dinamômetro de força muscular, futebol, análise discriminante.

\section{RESUMEN}

Introducción: La actividad muscular en jugadores de fútbol puede ser medida por medio del dinamómetro isocinético, que es un instrumento confiable para evaluación del desempeño humano. Objetivos: Conducir análisis isocinéticos y discriminar qué variables diferencian la categoría sub-17 (S17) de la profesional (PRO). Métodos: Fueron evaluados treinta y cuatro jugadores de fútbol ( $n=17$ para cada categoría). Las variables isocinéticas utilizadas para el análisis de extensión-flexión de la rodilla fueron: pico de torque (Nm), trabajo total (J), potencia media (W), ángulo de pico de torque (grados), razón agonista/antagonista (\%), probadas en tres velocidades (60\%s, $120 \% \mathrm{~s}$ y $300 \%$ s), con cada serie conteniendo cinco repeticiones. Fueron realizados tres análisis discriminantes usando el método Wilk's Lambda para identificar qué variables harían una discriminación significativa entre las dos categorías. Resultados: Las variables discriminantes a 60\% en la categoría PRO fueron: pico de torque extensores, trabajo total flexores, potencia media de extensores y razón agonista/antagonista; y para los S17 fueron: trabajo total de 
extensores, pico de torque de flexores y potencia media de flexores. A 120\%s para la categoría PRO las variables discriminantes fueron: pico de torque de flexores y potencia media de extensores; para los S17 fueron: trabajo total de extensores y potencia media de flexores. A 300\%, las variables encontradas para las categorías PRO y S17 fueron, respectivamente: potencia media de extensores y trabajo total de extensores. Conclusión: Las variables isocinéticas para los músculos de la rodilla flexores y extensores fueron capaces de hacer una discriminación significativa entre jugadores de fútbol PRO y 517.

Palabras clave: rodilla, dinamómetro de fuerza muscular, fútbol, análisis discriminante.

\section{INTRODUCTION}

Soccer is the most popular sport in the world and as all sports, it requires distinctive athletic features. Players have specific physical and psychological abilities, which are necessary to perform activities during matches ${ }^{1}$. The main action in soccer is running, achieving maximum effort during sprints, but other activities such as vertical jumps and kicking are also important for a successful performance ${ }^{2}$. All the aforementioned activities are dependent, in addition to other physical capacities, on lower limb strength ${ }^{3}$.

Lower limb muscle activity can be measured using an isokinetic dynamometer, which is the gold standard and a reliable tool for assessing human performance 4 . Its variables represent important features of muscle function ${ }^{5}$. Many studies have described the physiological and body profile of soccer players, demonstrating which variables are able to discriminate players ${ }^{6,7}$. However, there has been no study which has assessed muscle performance using isokinetic dynamometers to indicate the best variables in a report to differentiate players based on different match demands, physical features and age range. The most described variables in isokinetic tests for knee muscles of athletes are: peak torque, total work, average power and hamstring/quadriceps ratio, although it is still not clear which of these is the most important to report ${ }^{8}$. For instance, there are significant differences in peak torque between the professionals (PRO) and under 17 (U17) groups, being that both the hamstring and quadriceps muscles are stronger in the PRO category than in the U17s $\mathrm{s}^{9,10}$.

Discriminant analyzes allows the detection of which of the isokinetic variables could discriminate between the groups. This test is a multivariate statistical test that aims to identify which variables best discriminate or distinguish between two or more groups of distinctive individuals; to apply these variables as parameters which represent group differences; and to correctly classify new individuals to the specific groups ${ }^{11}$.

Due to high knee injury rates in soccer players and the importance of this joint and related muscle groups during match activities, its assessment is an important outcome not only for physical therapists, but also for improving player performance 4 . Furthermore, it is necessary to determine values of isokinetic variables for designating parameters to correctly classify players according to category. This is especially important for U17 players who are at the crucial moment of deciding whether they will continue to a professional career ${ }^{7}$. Thus, the aims of this study were to assess knee flexion and extension muscles of soccer players using an isokinetic dynamometer in two categories and to discriminate which isokinetic variables can differentiate players between the categories.

\section{METHODS}

This study was approved by Ethic Committee of the Universidade Estadual de Londrina (\#055/2012) and all participants provided informed written consent prior to the evaluation. Two groups of soccer players (PRO and U17) were assessed during the pre-season period (one month before competitions started). Each group was composed of 17 athletes who were instructed not to train on the day of the isokinetic assessment or in the afternoon of the preceding day. The sample size was calculated through $\mathrm{G}^{*}$ Power 3.1.9.2 ${ }^{12}$ using a two-tailed Student t-test to find the difference between two independent groups, effect size $=0.8$ and $\beta / \alpha=1$. Thirty-four subjects were necessary for a power of $82 \%$. The inclusion criteria were: absence of lower limb injuries in the preceding three months, for both groups; aged over 20 years for the PRO group and aged between 15 and 17 years for the U17 group. The characteristics of the participants are described in table 1.

The evaluations were carried out using a Biodex System 4 (Biodex Medical System Inc., Shirley, NY, USA) and the contraction mode chosen for the knee muscles was concentric, during the movement of flexion-extension. The dominant leg of each participant was assessed in a single session, at angular velocities of $60 \% 1 \mathrm{~s} 120 \% \mathrm{~s}$ and $300 \%$; each series contained five repetitions and was assessed only once in a random sequence with a 90 second rest interval between trials. The isokinetic variables analyzed were: peak torque, total work, average power, angle of peak torque and agonist/antagonist ratio, for all velocities. All evaluations were carried out by the same investigator and a variation coefficient below 10\% was employed to estimate whether trials were valid ${ }^{13}$.

The isokinetic evaluation was preceded by a 5 minute warm-up on a stationary bicycle, after which the participants were positioned on the seat of the equipment and stabilized, in order to avoid compensatory movements, with belts around the trunk, pelvis and the assessed thigh. The hip flexion was set at $85^{\circ}$ and the dynamometer axis was aligned with the anatomical axis, related to the lateral femoral epycondile. The lever arm length was determined as directly above the malleolus height ${ }^{14}$. All calibration procedures and gravity correction were in accordance with the instruction manual for the equipment. The range of motion was set at $90^{\circ}$, considering a maximum knee extension as $0^{\circ}$ and avoiding joint hyperextension. The athletes were instructed not to move their opposite lower limb and to perform maximum effort during all repetitions. Verbal encouragement and visual feedback were used to encourage the participants to develop maximum strength.

The Shapiro-Wilk test was used to verify sample distribution and the independent Student t test was applied for comparisons between groups of the isokinetic variables, height, weight and BMI. The Mann

Table 1. Characteristics of the participants.

\begin{tabular}{c|c|c|c}
\hline & $\overline{\mathbf{X}}($ SD) & $\overline{\mathbf{U 1 7}}$ & $\mathbf{P}$ \\
\hline Age $($ years old)* & $23(20-24)$ & $16(16-17)$ & $<0.001$ \\
\hline Height $(\mathrm{cm})$ & $181(5.2)$ & $176(10.9)$ & 0.10 \\
\hline Weight $(\mathrm{kg})$ & $78.5(6.8)$ & $69.8(8.6)$ & 0.003 \\
\hline BMl $\left(\mathrm{kg} / \mathrm{m}^{2}\right)$ & $23.9(1.9)$ & $22.4(1.8)$ & 0.031 \\
\hline Right-handed & 14 & 16 & - \\
\hline Left-handed & 3 & 1 & -
\end{tabular}


Whitney test was used only for the age variable. Three discriminant analyses were carried out using the Wilk's Lambda method to identify which of the variables related to the velocities $60 \% \mathrm{~s}, 120 \% \mathrm{~s}$ and $300 \% \mathrm{~s}$ would be able to significantly discriminate between the PRO and U17 groups. The matrices of homogeneity were tested using Box's M test of equality of covariance. The canonical correlation was applied to measure the association between the discriminant function and the group of variables. Following this, classificatory analysis and cross-validation demonstrated the allocation accuracy for each discriminant analysis. Statistical significance was set at 5\% and the statistical software used was SPSS version 22.0 (IBM SPSS ${ }^{\oplus}$, Armonk, NY, USA).

\section{RESULTS}

The comparisons between isokinetic variables according to groups and velocities are described in tables 2-4. The variables which did not present significant statistical differences were angle of peak torque during extension and agonist/antagonist ratio in all velocities, and angle of peak torque during flexion at $120 \% \mathrm{~s}$ and $300 \%$ s.

The homogeneity values of the variance-covariance matrices were $P=0.006,0.12$ and 0.2 at $60 \%, 120 \%$ s and $300 \%$, respectively. The standardized coefficients and canonical correlation values of each discriminant analysis are reported in table 5 . The discriminant variables for the PRO group at $60 \%$ s were: extension peak torque, flexion total work, extension average power and agonist/antagonist ratio. On the other hand, for the U17 group, the variables were: extension total work, flexion peak torque and flexion average power. At 120\% for the PRO group the discriminant variables were: flexion peak torque and extension average power. For the U17groupwere: extension total work and flexion average power. At $300 \%$, the variables found in the PROs and U17s were, respectively: extension average power and extension total work.
Table 5. Standardized coefficients and canonical correlation values of discriminant analysis.

\begin{tabular}{c|c|c|c}
\hline & $\mathbf{6 0} \% \mathbf{s}$ & $\mathbf{1 2 0} / \mathbf{s}$ & $\mathbf{3 0 0} / \mathbf{s}$ \\
\hline Extension peak torque & 1.697 & .632 & .807 \\
\hline Flexion peak torque & -1.206 & -2.440 & -.545 \\
\hline Extension total work & -2.910 & 3.057 & -3.636 \\
\hline Flexion total work & 2.333 & .457 & .189 \\
\hline Extension average power & 2.629 & -3.391 & 4.333 \\
\hline Flexion average power & -1.718 & 1.239 & -.496 \\
\hline Angle of extension peak torque & .015 & .166 & -.014 \\
\hline Angle of flexion peak torque & -.475 & .513 & -.012 \\
\hline A/AN ratio & 1.105 & -.086 & .966 \\
\hline Eigenvalue PRO & .925 & -1.272 & 1.238 \\
\hline Eigenvalue U17 & -.925 & 1.272 & -1.238 \\
\hline Wilk's lambda & .52 & .36 & .38 \\
\hline Significance & .03 & .001 & .002 \\
\hline Chi-square & 17.7 & 27.5 & 26.5 \\
\hline Canonical correlation & .79 & .78 & .69 \\
\hline
\end{tabular}

A/AN: agonist/antagonist, PRO: professional, U17: under-17.

The best canonical correlations were obtained for $60 \% \mathrm{~s}$ followed by $120 \%$ s and then $300 \%$, as described in Table 5 . The discriminant analyses which had the best classificatory analysis and cross validation values were $120 \%$ s and $300 \%$ s (91.2\% and $76.5 \%$ for both velocities) followed by $60 \%$ s (79.4\% and $64.7 \%)$.

\section{DISCUSSION}

The aim of this study was to assess knee flexion and extension movements of soccer players, in order to compare and carry out a discriminant analysis to differentiate between PRO and U17 players. The results may help to choose the safest and most appropriate moment

Table 2. Comparisons of isokinetic variables at $60 \% \mathrm{~s}$

\begin{tabular}{|c|c|c|c|c|c|c|}
\hline & \multicolumn{2}{|c|}{$\begin{array}{c}\text { Extension } \\
\overline{\mathrm{X}}(\mathrm{SD})\end{array}$} & \multirow[b]{2}{*}{$\mathbf{P}$} & \multicolumn{2}{|c|}{$\begin{array}{l}\text { Flexion } \\
\bar{X}(S D)\end{array}$} & \multirow[b]{2}{*}{$\mathbf{P}$} \\
\hline & PRO & U17 & & PRO & U17 & \\
\hline Peak torque (Nm) & $280.9(33.6)$ & $233.5(44.8)$ & 0.02 & $163.0(18.8)$ & $133.9(22.7)$ & $<0.001$ \\
\hline Total work $(J)$ & $1327.6(161.7)$ & $1109.4(227.5)$ & 0.03 & $889.8(109.5)$ & $724.1(124.4)$ & $<0.001$ \\
\hline Average power (W) & $183.1(23.6)$ & $150.6(27.8)$ & 0.01 & $116.4(15.6)$ & $94.8(17)$ & 0.01 \\
\hline Angle of peak torque $\left(^{\circ}\right)$ & $62.4(3.37)$ & $64(5.7)$ & 0.33 & $29.4(7.6)$ & $36.7(12.7)$ & 0.05 \\
\hline A/AN ratio $(\%)$ & $58.3(6.4)$ & $57.9(5.9)$ & 0.86 & - & - & - \\
\hline
\end{tabular}

A/AN: agonist/antagonist, PRO: professional, U17: under-17, SD: standard deviation.

Table 3. Comparisons of isokinetic variables at $120 \%$ s.

\begin{tabular}{|c|c|c|c|c|c|c|}
\hline & \multicolumn{2}{|c|}{$\begin{array}{c}\text { Extension } \\
\bar{X}(S D)\end{array}$} & \multirow[b]{2}{*}{$\mathbf{P}$} & \multicolumn{2}{|c|}{$\begin{array}{l}\text { Flexion } \\
\bar{X}(S D)\end{array}$} & \multirow[b]{2}{*}{$P$} \\
\hline & PRO & U17 & & PRO & U17 & \\
\hline Peak torque (Nm) & $229.7(27.4)$ & $189.6(35.9)$ & 0.001 & $139.5(15.8)$ & $113.69(18.6)$ & $<0.001$ \\
\hline Total work (J) & $1148.6(154.2)$ & $965.1(118.8)$ & 0.005 & $778.4(123.7)$ & $661.8(118.8)$ & 0.09 \\
\hline Average power (W) & $286.9(34.4)$ & $234.1(46.9)$ & 0.001 & $185.7(26.9)$ & $156.9(27.3)$ & 0.004 \\
\hline Angle of peak torque $\left({ }^{\circ}\right)$ & $61.1(3.0)$ & $60.3(4.4)$ & 0.59 & $61.1(6.8)$ & $60.7(7.0)$ & 0.86 \\
\hline A/AN ratio (\%) & $35.2(8.6)$ & $38.1(7.7)$ & 0.31 & - & - & - \\
\hline
\end{tabular}

A/AN: agonist/antagonist, PRO: professional, U17: under-17, SD: standard deviation.

Table 4. Comparisons of isokinetic variables at $300 \%$ s.

\begin{tabular}{|c|c|c|c|c|c|c|}
\hline & \multicolumn{2}{|c|}{$\begin{array}{l}\text { Extension } \\
\bar{X}(S D)\end{array}$} & \multirow[b]{2}{*}{$P$} & \multicolumn{2}{|c|}{$\begin{array}{l}\text { Flexion } \\
\bar{X}(S D)\end{array}$} & \multirow[b]{2}{*}{$\mathbf{P}$} \\
\hline & PRO & U17 & & PRO & U17 & \\
\hline Peak torque (Nm) & $155.2(27.9)$ & $125.4(22.4)$ & $<0.001$ & $99.1(16.9)$ & $78.1(10.1)$ & $<0.001$ \\
\hline Total work (J) & $675.5(115.2)$ & $544.9(109.0)$ & $<0.001$ & $440.2(102.2)$ & $357.8(70.8)$ & 0.01 \\
\hline Average power (W) & $349.8(54.0)$ & $268.7(49.6)$ & $<0.001$ & $209.1(43.8)$ & $162.9(30.0)$ & $<0.001$ \\
\hline Angle of peak torque $\left(^{\circ}\right)$ & $61.1(3.0)$ & $60.3(4.4)$ & 0.61 & $33.8(5.9)$ & $35.1(8.7)$ & 0.56 \\
\hline A/AN ratio (\%) & $63.8(7.4)$ & $63.1(8.1)$ & 0.80 & - & - & - \\
\hline
\end{tabular}


to introduce a young soccer player to the PRO category. This decision can take into consideration the physical performance according to an isokinetic evaluation and the discriminant function described in agreement with other physical indexes.

When comparing the values of each variable and their respective velocities, all variables showed significant statistical differences, except for the following: angle of peak torque for extension, agonist/antagonist ratio, for all velocities and angle of peak torque during flexion at $120 \%$ and $300 \%$, with higher values for the PRO players. Lehance ${ }^{15}$ also found differences regarding the concentric extension peak torque when comparing U17s and PROs. Nevertheless, all reported values for both groups and muscles were lower than in this study.

Herdy ${ }^{16}$ compared the average torque of soccer players in three different categories: U17s, under-20s and PROs, at 60\%s, over 5 repetitions. The only significant statistical difference found was for the U17 knee flexion compared to the PRO. Furthermore, Fousekis ${ }^{17}$ assessed the muscle performance of soccer players according to their training age and reported that peak torque increased as the athletes became more experienced. The players with 8 to 10 years' experience demonstrated higher values than less experienced practitioners. Thus, the lower values found for the U17s in comparison to the PROs may have been influenced by this parameter, in addition to the difference in biological maturity between the groups ${ }^{18}$.

Dervisevic and Hadzic ${ }^{19}$ suggested that in order to assess team sport athletes, only two trials at different velocities are necessary due to the high time demand required to evaluate all members. Moreover, the authors recommended the velocities of $60 \% \mathrm{~s}$ and $120 \% \mathrm{~s}$ or $60 \% \mathrm{~s}$ and $180 \%$ s. Nevertheless, considering the aim of this study to perform a complete analysis of the soccer players' muscle performance profile, we felt that three velocities were needed. The slowest velocity had the best reproducibility and was also the velocity which best identified strength deficits between the legs or muscle groups ${ }^{19}$. The highest velocity is important for simulating the controlled assessment performed inside a laboratory in comparison to sports actions occurring in a match (e.g.: In a kick the lower leg can reach velocities of higher than $\left.1000^{\circ} / \mathrm{s}\right)^{3}$.

Another important point to consider in a high velocity trial is the aptitude of the muscle to enroll different types of muscle fibers. When the velocity is too high, the time taken to recruit the slow-twitch fibers is short; however under a condition of slow velocity, both slow and fast-twitch fibers may achieve full activation. Consequently, when the angular velocity increases, the slow-twitch fibers remain passive to the movement, as the time to achieve the intended velocity is higher, thus the characteristic of velocity constancy is lower than at slower velocities ${ }^{20}$.

The isokinetic variables peak torque, total work and average power measure the different capacities of a muscle, although they are all correlated with the ability of the muscle to contract and generate strength $^{21}$. The discriminant variables for the PROs at $60 \%$ demonstrated the muscles required to execute specific tasks related to the game. The force generated by the quadriceps, measured by the peak torque and its contraction ability as well as determined by the average power, is related to actions like kicking, jumping and sprinting. Both parameters illustrate the essential aptitude of this muscle group to produce force and also to manage it quickly and efficiently. In contrast, the antagonist activity of the hamstrings is essential for the deceleration of the knee, controlling the joint motion. This function is denoted by the total work of the flexion muscles, which ally the torque, changing according to the knee's range of motion; this variable shows, in general, the behavior of the muscle throughout the movement, as opposed to the peak torque 22 .The relationship described above points to another discriminant variable, the agonist/antagonist ratio. The assessed sample presented no discrepancy regarding muscle balance, thus showing the importance of the hamstrings for joint balance ${ }^{10}$.

The U17 group presented opposite discriminant variables. The knee extension muscles achieve their maximum development at the age of 21 years, after this the maximum values of peak torque reach a plateau and large differences between age groups are no longer apparent. In contrast, the knee flexion muscles have their period of greatest development at the age of 16 years, therefore, in our sample, the majority of individuals had already progressed to their upper limit. According to Malina ${ }^{23}$, biological maturity influences several skills such as dribbling for a pass, ball control with the head, ball control with the body and kicking accuracy. Thus, the muscle demand is different between these groups.

Another important factor to consider is the window adaptation period. The magnitude of physical capacity adaptations, specifically strength, is influenced by the neuromuscular characteristics and varies according to each athlete. After several years of practicing, the athlete has a faster response to the stimuli produced by training ${ }^{24}$. Thus, PRO athletes may have higher values for isokinetic variables due to their faster physiological adaptation during pre-season.

The discriminant variables for the PRO group at $120 \%$ (flexion peak torque and extension average power) and at $300 \%$ s (extension average power) emphasize the necessity of thigh muscles to produce power in a very short time period. For the U17s the extension total work, which was a discriminant variable at $120 \% \mathrm{~s}$ and $300 \%$ s, reinforces the different demands during matches for both groups. Due to the U17 players still not having achieved their maximum extension strength, an opposite dynamic behavior for the muscle is required, not solely based on peak actions ${ }^{25}$.

The canonical correlation indicates how useful each discriminant function could be in determining differences between groups ${ }^{26}$. Canonical correlation is a measure of the association between groups of variables and the discriminant function. A value close to 1 suggests that the variance in the discriminant scores can be attributed to groups' differences, explained by the given function ${ }^{26}$.

Classificatory analysis is used to evaluate the accuracy of a discriminant function regarding the correct classification of a participant according to their group. The cross-validation estimates the allocation accuracy of each participant in accordance with all cases ${ }^{11}$. The percentages of each classificatory analysis were higher than the classification by chance alone, 50\%, in this study. Furthermore, an important issue is the better accuracy of the higher velocities to discriminate between these two soccer categories.

Some limitations in this study should be addressed. Although soccer players of two different age categories were assessed, it was not possible to perform discriminant analysis to differentiate playing positions. As described by Carvalho ${ }^{27}$ and Tourny-Chollet ${ }^{28}$ there are differences according to playing positions, mainly at $60 \%$ s. Only the concentric contraction mode was performed in this study; as an aside, eccentric contraction contributes to a complete report of the muscle profile and also to report the functional ratio. This ratio considers the eccentric flexion peak torque in relation to the concentric extension peak torque ${ }^{29}$.

Some implications for practice can be suggested. The isokinetic dynamometer is a reliable tool for assessing muscle performance and for investigating unbalanced forces between muscle groups ${ }^{8}$. The muscle groups with the highest injury rate during the season, besides the hip adductors, are the quadriceps and the hamstrings; however during pre-season the extension knee muscles have the highest incidence of injury ${ }^{30}$.

Thus, the discriminant variables are standards by which to compare soccer players in similar conditions to this study. The reported values 
support, during pre-season, the staff working on the fitness of players and the avoidance of injuries during competitions. Furthermore, an individualized analysis of the muscle features of each athlete can be realized based on these results. Moreover, the early exposure of an U17 player to an inappropriate match demand can be prevented through the correct allocation into a group.

\section{CONCLUSION}

Discriminant analysis using isokinetic variables for flexion and extension knee muscles was able to significantly discriminate between PRO and U17 soccer players. At $60 \%$ s for the PRO group they were: extension peak torque, flexion total work, extension average power and agonist/antagonist ratio; in the U17 group they were: extension total work, flexion peak torque and flexion average power. At $120 \%$ for the PRO group they were: flexion peak torque and extension average power; for the U17group they were: extension total work and flexion average power. At $300 \%$ for the PRO and U17 groups respectively they were: extension average power and extension total work.

\section{ACKNOWLEDGEMENTS}

The authors wish to thank the Londrina Esporte Clube (LEC) and the Junior Team Futebol for their support by providing players to the assessment, Prof. Fabio Y. Nakamura, Physiologist, PhD, for his partnership and his skill in writing the project that was approved by FINEP (Financiadora de Estudos e Projetos, grants \# 01/2007) and Carci Company for its assistance with the isokinetic dynamometer.

All authors have declared there is not any potential conflict of interests concerning this article.

\section{REFERENCES}

1. Manning MR, Levy RS. Soccer. Phys Med Rehabil Clin N Am. 2006;17(3):677-95

2. Stolen T, Chamari K, Castagna C, Wisloff U. Physiology of soccer. Sports Med. 2005;35(6):501-36

3. Lees A, Nolan L. The biomechanics of soccer: A review. J Sports Sci. 1998;16(3):211-34

4. Caruso JF, Brown LE, Tufano JJ. The reproducibility of isokinetic dynamometry data. Isokinet Exerc Sci. 2012;20(4):239-53

5. Rahnma N, Bambaieichi E. Musculoskeletal assessment in soccer: A review. J Move Sci Sports. 2008;1:13-24

6. Phillipaerts RM, Vaeyens $R$, Janssens M, Van Renterghem B, Matthys D, Craen R, et al. The relationship between peak height velocity and physical performance in youth soccer players. J Sports Sci. 2006;24(3):221-30.

7. Williams AM, Reilly T. Talent identification and development in soccer. J Sports Sci. 2000;18(9):657-67.

8. Rochcongar P. Isokinetic thigh muscle strength in sports: a review. Ann Readapt Med Phys. 2004:47(6):274-81.

9. Croisier JL, Reveillon V, Ferret JM, Cotte T, Genty M, Popovich N, et al. Isokinetic assessment of knee flexors and extensors in professional soccer players. Isokinet Exerc Sci. 2003;11(1):61-2.

10. Croisier JL, Ganteaume S, Binet J, Genty M, Ferret JM. Strength imbalance and prevention of hamstring injury in professional soccer players. A prospective study. Am J Sports Med. 2008;36(8):1469-75

11. Marôco J. Statistical analyses with SPSS. Pero Pinheiro: ReportNumber; 2011.

12. Faul F, Erdfelder E, Lang AG, Buchner A.G. G*Power 3: a flexible statistical power analysis program for the social, behavioral, and biomedical sciences. Behav Res Methods. 2007;39(2):175-91.

13. Lin PC, Robinson ME, Junior JC, O' Connor P. Detections of submaximal effort in isometric and isokinetic knee extension tests. J Orthop Sports Phys Ther. 1996;24(1):19-24.

14. Houwelling TAW, Hamzeh MA. Does knee joint alignment with the axis of the isokinetic dynamometer affect peak torque? Isokinet Exerc Sci. 2010;18(4):217-21.

15. Lehance C, Binet J, Bury T, Croisier JL. Muscular strength, functional performances and injury risk in professional and junior elite soccer players. Scand J Med Sci Sports. 2009;19(2):243-51.

16. Herdy C, Alkimim R, James S, Pedrinelli A. Isokinetic testing of athletes Brazilian U17, U20 and profes- sional. 22nd International Conference on Sports Rehabilitation and Traumatology: Football medicine strategies for muscle and tendon injuries, 1-2; 2013

17. Fousekis $K$, Tsepis E, Vagenas G. Lower limb strength in professional soccer players: profile, asymmetry, and training age. J Sports Sci Med. 2010;9(3):364-73.

18. Holm I, Steen H, Olsta M. Isokinetic muscle performance in growing boys from pre-teen to maturity. An eleven-year longitudinal study. Isokinet Exerc Sci. 2005;13(2):153-8.

19. Dervisevic E, Hadzic V. Quadriceps and hamstrings strength in team sports: Basketball, football and volleyball. Isokinet Exerc Sci. 2012;20(4):293-300.

20. Kannus P. Isokinetic evaluation of muscular performance: implications for muscle testing and rehabilitation. Int J Sports Med. 1994;15 Suppl:S11-18.

21. Kannus P. Peak torque and total work relationship in the thigh muscles after anterior cruciate ligament injury. J Orthop Sports Phys Ther. 1988;10(3):97-101.

22. Reilly T. The science of training soccer. Abingdon: Routledge; 2007.

23. Malina RM, Cumming SP, Kontos AP, Eisenmann JC, Ribeiro B, Aroso J. Maturity-associated variation in sport -specific skills of youth soccer players aged 13-15 years. J Sports Sci. 2005;23(5):515-22.

24. Cormie P, McGuigan MR, Newton RU. Developing maximal neuromuscular power. Part 2 - training considerations for improving maximal power production. Sports Med. 2011;419(2):125-46.

25. Stolen T, Chamari K, Castagna C, Wisloff U. (2005). Physiology of soccer. Sports Med. 2005;35(6):501-36 26. Garson D. Discriminant function analysis: Blue book series. Ebook: Statistical Associates Publishing; 2012.

27. Carvalho P, Cabri P. Isokinetic strength evaluation of the thigh muscles in soccer players. Port J Sport Physiother. 2007;1(2):4-13

28. Tourny-Chollet $C$, Leroy $D$, Léger $H$, Beuret-Blanquart F. Isokinetic knee muscles strength of soccer players according to their position. Isokinet Exerc Sci. 2000;8(4):187-93.

29. Aagard P, Simonsen EB, Magnusson SP, Larsson B, Dyhre-Poulsen P. A new concept for isokinetic hamstring: quadriceps muscle strength ratio. Am J Sports Med. 1988;26(2):231-7.

30. Hagglund $M$, Walden $M$, Ekstrand J. Risk factors for lower extremity muscle injury in professional soccer players. Am J Sports Med. 2012;41(2):327-35. 